\title{
The Effect of Red Pomegranate Provision on Malondialdehyde and Blood Lactic Acid Level in Rats with Maximum Physical Activity
}

\author{
Ahmad Zainuddin ${ }^{1 *}$, Hardhono Susanto ${ }^{2}$, Ali Rosidi ${ }^{3}$ \\ ${ }^{1}$ Study Program of Nutrition, Faculty of Medicine, Diponegoro University, Semarang 50275, Indonesia \\ ${ }^{2}$ Anatomic Pathology Section, Faculty of Medicine, Diponegoro University, Semarang 50275, Indonesia \\ ${ }^{3}$ Nutritional Science Courses, Universitas Muhammadiyah Semarang, Semarang 50273, Indonesia
}

\begin{abstract}
The primary objective of this research was to examine the effect of provision of red pomegranate juice on the levels of malondialdehyde (MDA) and blood lactic acid in Wistar rats with maximum physical activity. The study employed a true experiment design. The pretest-posttest with control group design was done on 35 rats given maximum physical activity and treatment for 28 days. The rats were divided into 5 groups: the control group, group with treatment of multivitamin, group with treatment of red pomegranate $2 \mathrm{ml}, 4 \mathrm{ml}$, and $6 \mathrm{ml}$. The MDA level was measured by TBARS method and lactic acid levels were analysed using ELISA. Comparison statistical analysis was done using paired t-test, while comparison of mean differences between treatment groups were tested using One-way ANOVA, and followed by LSD as the post hoc test. Provision of red pomegranate juice in a variety of doses significantly decreased the levels of MDA and blood lactic acid $(\mathrm{p}<0.05)$. The highest MDA level decrease occurred in the group treated with multivitamin $(68.02 \%)$ and the highest decrease in the levels of blood lactic acid occurred in the group with $6 \mathrm{ml}$ red pomegranate juice (25.94\%). Based on the findings, it can be concluded that red pomegranate juice can lower the levels of MDA and blood lactic acid significantly in rats with maximum physical activity.
\end{abstract}

Keywords: lactic acid, malondialdehyde, maximum physical activity, pomegranate

\section{INTRODUCTION}

Physical exercises known have many benefits to improve health. Exercises that performed correctly will have a positive impact on the fitness of the body and achievements (Purnomo 2011). However, physical exercises can also bring negative effects, one of them is the formation of free radicals and lactic acid (Guyton \& Hall 2011). Exercises conducted redundantly coupled with lack of rest time will negatively affect physical and psychological aspects (Quinn et al. 2008). Loads of exercise improves the performance of athletes however, not all athletes are equipped with the right knowledge or skill on managing load exercises (Saputro \& Junaidi 2015).

Excessive sports activity can increase the occurrence of oxidative stress (Wang et al. 2007). In addition, physical activities performed with maximum intensity and in exhausting conditions would cause hypoxia. Hypoxia will lead to decrease in the amount of oxygen available for cells, which increase mitochondrial electron leakage which becomes free radicals or Reactive Oxygen Species (ROS). Hypoxia also increases the accumulation of lactic acid in the blood due to mitochondrial damage caused by free radicals and increase cycle of anaerobic metabolism, this will lead to decline of the overall physical condition (Rosidi et al. 2013).

The present of increased oxidative stress can be detected by high levels of Malondialdehyde (MDA) and decrease in enzymatic antioxidants such as Superoxide dismutase (SOD). MDA is the result of the degradation of lipids and is an indirect analysis in determining the amount of free radicals. Due to its stability, MDA is better than peroxide lipids that had a short time and it is difficult to be examined directly to be used as a biomarker of oxidative stress (Harun et al. 2017).

The research done by Turner et al. (2011) showed that athletes run approximately $233 \mathrm{~km}$ produced oxidative stress that last up to one month. The maximum physical activity for rats that deployed during researchs to imitate the condition like athletes with excessive physical activity was swimming as hardest as they could. They swimming until they got exhausted and experienced an increase in oxidative stress and blood lactic acid. Exhaustion indicators were indicated by sinking they body parts except the nose. The spread of free radicals in the body can be over-

"Corresponding Author: tel: +6285326619690, email: zaenudinahmad52@gmail.com 
come by endogenous antioxidants, but if the endogenous antioxidant is fewer than the number of free radicals in the body, additional antioxidants (exogenous) are needed to neutralize the free radicals formed (Sayuti \& Yenrina 2015).

Many studies have shown the utilization of certain types of fruits to prevent muscle fatigue, one of them is pomegranate. Punica granatum or red pomegranate is one of nutritious food crops with a nutraceutical (Syamsudin 2013). The pomegranate has been shown to contain antioxidants that can inhibit oxidative stress and also be able to repair body cells that are damaged (Vegara et al. 2013).

Red pomegranate is a fruit that contains high antioxidants and a good source of phenolic compounds, such as polypeptide, flavonoids, phenolic acids, and polyphenols that contribute to a high antioxidant capacity (Trexler et al. 2014). Pomegranate juice contains antioxidant activity three times higher than the green tea polyphenols and the total concentration is higher than fruit juices, such as orange, grape, cranberry, pineapple, and apple juice. Anthocyanin is one of powerful antioxidants that can neutralize the amount of free radicals in the body so that the body's cells can avoid damages caused by oxidative stress (Lilach et al. 2014).

Based on the background, the research will focus on the influence of giving of red pomegranate with a dose of $2 \mathrm{ml}, 4 \mathrm{ml}$, and $6 \mathrm{ml}$ for 28 days towards MDA and blood lactic acid levels in male Wistar rats given maximum physical activity. This research aims to examine the effects of red pomegranate juice on the levels of MDA and blood lactic acid levels in Wistar rats with maximum physical activity.

\section{METHODS}

\section{Design, location, and time}

The research employed an experimental design with pretest and posttest with control group design. This research was conducted in Laboratory Animal Experiments of Diponegoro University. This research was conducted within a period of August-October 2017.

\section{Materials and tools}

The tools and materials used were animal cages, feed containers, container drink aquades, waterbath with depth of $50 \mathrm{~cm}$, stopwatch, digital scales with accuracy of 0.1 gram, tube microhematocrit and vial to take a blood sample, the spuit sonde syringe for giving red pomegranate juice on rats, the tool checks the levels of MDA and blood lactic acid levels. Materials consist of Comfeed AD II, red pomegranate that came from the Colo Village, Kudus, Central Java, commercial multivitamin, and reagent MDA and lactic acid.

\section{Sampling}

The subjects used were male Wistar rats aged 2-3 months, weight $\pm 200 \mathrm{~g}$, healthy, and physically active. Rats undergone drastic weight loss at the time of adaptation were excluded and drop out was done when the rats died during the research. The samples included 35 rats which were divided into 5 groups, Group X0 (control), $\mathrm{X} 1$ (treatment multivitamin), X2, X3 group, and $\mathrm{X} 4$ (treatment of Pomegranate juice). The research has been approved by the Commission on health research Ethics (KEPK) Faculty of Medicine Diponegoro University No. 02/EC/H/ FK-RSDK/I/2018.

\section{Procedures}

Research was done after identification and analysis of bioactive substance of red pomegranate juice. As many as 35 rat followed acclimatization for 7 days with the given standard feed with comfeed AD II and aquades ad libithum, swimming pool test introduction for 4 days with the aim of finding out the maximum time for a rat in doing physical activity that will be used as the basis for the duration of the treatment. Initial weighing was performed on the last day of the preliminary test and the blood taking pretest was conducted via the plexus retroorbitalis.

The rats were given maximum physical activity for 28 days as the induction of oxidative stress. They were then divided into 5 groups: the $\mathrm{X} 0$ as the control group, the $\mathrm{X} 1$ given supplements multivitamin with a dose of $4.5 \mathrm{mg}$ of homogeneous into $4 \mathrm{ml}$ and administered with sonde the stomach. X2 given $2 \mathrm{ml}$ filtered-blended red pomegranate, $\mathrm{X} 3$ given $4 \mathrm{ml}$ filtered-blended red pomegranate, and $\mathrm{X} 4$ given $6 \mathrm{ml}$ filtered-blended red pomegranate. The multivitamin and red pomegranate treatment were given twice daily, i.e. every morning and afternoon.

The weight after treatment were measured every week during the treatment until day 28 . The blood samples were drawn in the last day of treatment via the plexus retroorbitalis then analysed using Thiobarbituric Acid Reactive Substances (TBARS) for MDA measurements and using ELISA for blood lactic acid level measurements using a spectrophotometer with a wavelength of $520-600 \mathrm{~nm}(565 \mathrm{NM})$. TBARS is probably the 
oldest and one of the most widely used assays for measuring lipid peroxidation end product malondialdehyde (Dasgupta \& Klein 2014). The method of ELISA using a kit from BioAssay System manufacturer, USA and was done following to the instructions provided in the guidelines book.

MDA level measurements was done in the laboratory of Biochemistry at the University of Diponegoro and lactic acid levels test conducted at Food Technology Integrated Laboratory in the Diponegoro University. Both are commonly used Laboratory researchers to test sample.

The stages in testing the levels of MDA are 1) $50 \mu 1$ blood plasma from each sample was inserted into a tube measuring $13 \mathrm{ml}$ polypropylene; 2) $750 \mu 150 \mu 1$ posphate acid, Tetra Ethoxy Propane (TEP), and divorteks were added; 3) 250 $\mu 1$ of solution Tiobarbiturat Acid solution (TBA) $40 \mathrm{nM}$ and aquades as much as $450 \mu 1$ were added into each tube; 4) the tube was closed tightly then heated at a temperature of $100^{\circ} \mathrm{C}$ for one hour; 5) after warming, the tube was placed in the ice bath to cool the sample; 6) sample already applied to the cold in this set pack C18; and 7) it was then measured with absorbance spectrophotometer with a wavelength of $532 \mathrm{~nm}$.

\section{Data Analysis}

Data normality was tested with Shapiro Wilk for total sample of $<50$. The difference in mean MDA levels and mean blood lactic acid level within groups, before and after the pomegranate treatment were tested using Paired t-test. The difference of effect of treatment the three groups base on different doses of red pomegranate juice were analysed using One-way ANOVA followed by LSD Post Hoc test.

\section{RESULTS AND DISCUSSION}

The red pomegranate used was identified in plant taxonomy from Magnoliopsida class, Dicotyledoneae (two seed leaves). Table 1 shows that red pomegranate juice has the total flavonoids of $291.279 \mathrm{ppm}$ and total anthocyanin of $8.761 \mathrm{ppm}$, whereas the activity of antioxidants was $36.662 \%$ discoloration. This red pomegranate from Kudus has higher total flavonoids than red pomegranate from South Africa who had the contents of total flavonoids of $233.5 \mathrm{ppm}$, while the total deposit of antioxidants in the red pomegranate from Kudus is lower than South African red pomegranate with a total of anthocyanin of 10.96 ppm (Mphahlele et al. 2016).

\section{Weight of rats}

Weighing the rats was aimed at monitoring the weight changes of the rat during the intervention and will be linked to maximum physical activity and the provision of red pomegranate juice. The development of rat body weight on the Group X0, X1, xX2, X3, and X4 during the study. Changes of the rat's body weight every week started from the acclimatization until after the intervention can be seen in Figure 1. The biggest weight gain was present in the $\mathrm{X} 1$ group, which is the group administered with multivitamin, and the group with the lowest wight gain was present on the X2, which is the group administered with $2 \mathrm{ml}$ of red pomegranate juice.

The increase in weight occurred because the rats experienced oxidative stress and fatigue due to excessive exercise so as to increase the hunger. Such conditions will cause the rats to eat more servings. The research is in line with the research of Harun et al. (2017) which explained that rats given a high physical activity in the form of pools experienced increased weight of $10.8 \%$.

Paired t-test results showed an increase in body weight of rats after intervention on all of the groups signifficantly $(p<0.05)$. One-way ANOVA test obtained a result that there was no meaningful difference in average body weight of a rat among the Group X0, X1, X2, X3, and X4 $(p>0.05)$. This suggests that weight gain between groups prior to the granting of the preferential treatment is homogenous. Based on the One-way ANOVA test, there was also no signifficant difference in the increase of weight in the groups

Table 1. Antioxidant activity, total flavonoid, and anthocyanin of Kudus red pomegranate juice

\begin{tabular}{lccc}
\hline Sample & $\begin{array}{c}\text { Antioxidant } \\
\text { activity (\%) }\end{array}$ & $\begin{array}{c}\text { Total } \\
\text { flavonoid } \\
\text { (ppm) }\end{array}$ & $\begin{array}{c}\text { Total } \\
\text { anthocyanin } \\
\text { (ppm) }\end{array}$ \\
\hline $\begin{array}{l}\text { Pomegranate } \\
\text { juice }\end{array}$ & 36.662 & 291.279 & 8.761 \\
\hline
\end{tabular}

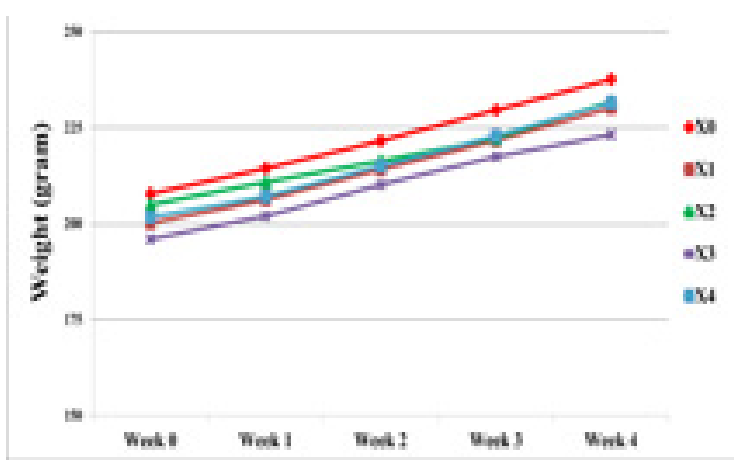

Figure 1. Average weight of rats per week 
after intervention $(p>0.05)$. Excessive physical activity will increase free radicals in the body and lead to hypoxia. The state of hypoxia will interfere the body's metabolic system and have an impact on weight gain or weight loss drastically (Rosidi et al. 2013).

\section{Red pomegranate juice effect on MDA level}

The average change of plasma MDA levels before and after the provision of the red pomegranate juice can be seen in Table 3 . The Paired t-test showed a significant decrease $(p<0.05)$ in the levels of MDA in Group X1 with multivitamin, followed by $\mathrm{X} 4, \mathrm{X} 3$, and then $\mathrm{X} 2$, which was provised with $6 \mathrm{ml}, 4 \mathrm{ml}$, and $2 \mathrm{ml}$ of red pomegranate respectively. Group X0 or the control group showed no difference in the average plasma MDA levels ( $\mathrm{p}>0.05)$.

The LSD Post Hoc test showed that average changes in plasma MDA level were differ significantly between $\mathrm{X} 0$ with $\mathrm{X} 1, \mathrm{X} 2, \mathrm{X} 3$, and $\mathrm{X} 4$, also between $X 2$ with $X 1$ and $X 4(p<0.05)$. Group X1 experienced a larger decline in average plasma MDA levels (-68.02 $\pm 3.91 \%)$ compared to X4 $(-60.38 \pm 3.2 \%)$, while $\mathrm{X} 0$ experienced increase in the levels of plasma MDA levels $(10.12 \pm 3.66 \%)$.

Maximum physical activity that is conducted continuously will cause an increase in oxygen consumption, which reaches 20 times larger than the normal requirements and results in the endogenous antioxidants as the natural defence of the body not able to cope with the number of free radicals formed that can attack the cell membrane (Susanna 2011). This research is also in line with previous research which shows that giving a rich anthocyanin strawberry supplementation for
30 days against 23 healthy volunteers (11 men and 12 women) can lower serum malondialdehyde $(31.40 \% ; p<0.05)$ and significantly increase the antioxidant status such as Ferric Reducing Ability of Plasma (FRAP), Oxygen Radical Absorbance Capacity (ORAC) Assay, and vitamin C levels $(24.97 \%, 41.18 \%, 41.36 \% ; \mathrm{p}<0.05)$ (Jose et al. 2014).

Red pomegranate has a content of polyphenols which consists of anthocyanin, catechins, ellagic, gallic tannins, ellagic acid, and vitamin $\mathrm{C}$ as an antioxidant. Antioxidants had a role as the protector of the body from oxidation chain reaction. Antioxidants have a role as electron donors to neutralize free radicals and molecules that formed by them, also destroying free radicals before it can cause damage (Sreekumar et al. 2014).

The red pomegranate used in this study research has $291.279 \mathrm{ppm}$ of flavonoids content, that this compounds thought to be the most influential compounds to cause a decrease in the levels of MDA. The results of this study are in line with Jawi et al. (2008) that showed that the extracts from sweet potato contains antioxidant compounds that can lower the plasma MDA levels in heavy physical activity rats (Jawi et al. 2008). The $6 \mathrm{ml}$ red pomegranate juice given to rats when converted to humans is equal to $360 \mathrm{ml}$ that has $43.68 \mathrm{mg}$ flavonoids content.

\section{Red pomegranate juice effect on blood lactic acid levels}

The average changes of lactic acid levels in rats before and after treatment can be seen in table 4 . The result from Paired t-test showed a significant decline $(\mathrm{p}<0.05)$ in blood lactic acid

Table 2. Average weight of rats after 28 days red pomegranate juice intervention

\begin{tabular}{lcccccc}
\hline Weight & \multicolumn{5}{c}{ Mean \pm SD } & \multirow{2}{*}{$\mathrm{p}^{1}$} \\
\cline { 2 - 6 } & $\mathrm{X} 0(\mathrm{n}=5)$ & $\mathrm{X} 1(\mathrm{n}=7)$ & $\mathrm{X} 2(\mathrm{n}=6)$ & $\mathrm{X} 3(\mathrm{n}=6)$ & $\mathrm{X} 4(\mathrm{n}=7)$ & 0.867 \\
\hline Before & $207.8 \pm 20.69$ & $200.1 \pm 18.86$ & $205 \pm 18.25$ & $196 \pm 16.52$ & $201.7 \pm 21.30$ & 0.867 \\
After & $237.6 \pm 14.77$ & $230.1 \pm 21.60$ & $231.8 \pm 20.53$ & $223.2 \pm 19.24$ & $231.6 \pm 18.09$ & 0.805 \\
$\Delta$ & $29.8 \pm 6.14$ & $30.0 \pm 3.36$ & $26.8 \pm 8.42$ & $27.2 \pm 5.41$ & $29.9 \pm 9.56$ & 0.956 \\
$\mathrm{p}^{*}$ & 0.000 & 0.000 & 0.000 & 0.000 & 0.000 & \\
\hline *Paired t-test $\mathrm{p}<0.05 ;{ }^{1}$ One-way & & & & &
\end{tabular}

Table 3. Average levels of MDA before and after 28 days the red pomegranate juice intervention

\begin{tabular}{lcccccc}
\hline \multicolumn{1}{c}{ The levels of } & \multicolumn{5}{c}{ Mean \pm SD } & \multirow{2}{*}{$\mathrm{p}^{1}$} \\
\cline { 2 - 6 } MDA $(\mathrm{nmol} / \mathrm{ml})$ & $\mathrm{X} 0(\mathrm{n}=5)$ & $\mathrm{X} 1(\mathrm{n}=7)$ & $\mathrm{X} 2(\mathrm{n}=6)$ & $\mathrm{X} 3(\mathrm{n}=6)$ & $\mathrm{X} 4(\mathrm{n}=7)$ & \\
\hline Before & $8.48 \pm 3.84$ & $8.44 \pm 3.76$ & $8.34 \pm 2.85$ & $8.38 \pm 4.68$ & $8.39 \pm 3.46$ & 1.000 \\
After & $9.34 \pm 1.98^{\mathrm{a}}$ & $2.70 \pm 1.62^{\mathrm{b}}$ & $5.76 \pm 1.72^{\mathrm{c}}$ & $3.65 \pm 1.53^{\mathrm{b}}$ & $3.32 \pm 2.75^{\mathrm{b}}$ & 0.000 \\
$\Delta$ Pre-Post & $0.86 \pm 3.10$ & $-5.74 \pm 3.30$ & $-2.57 \pm 1.99$ & $-4.69 \pm 2.52$ & $-5.06 \pm 2.68$ & 0.004 \\
\% Decrease & $10.12 \pm 3.66$ & $-68.02 \pm 3.91$ & $-30.9 \pm 2.63$ & $-56.27 \pm 3.03$ & $-60.38 \pm 3.2$ & \\
$\mathrm{p}^{*}$ & 0.570 & 0.004 & 0.035 & 0.006 & 0.002 & \\
\hline *Paired t-test; ${ }^{*}$ One-way ANOVA test; a,b,c On the &
\end{tabular}

*Paired t-test; ${ }^{1}$ One-way ANOVA test; ${ }^{\text {a,b,c }}$ On the same line, the number with same letters show no significant differences between the group $(\mathrm{p}>0.05)$ (Post Hoc LSD) 
Red pomegranate on MDA and blood lactic acid level

Table 4. Average levels of blood lactic acid before and after intervension of the red pomegranate juice for 28 days

\begin{tabular}{lcccccc}
\hline $\begin{array}{l}\text { Levels of } \\
\text { lactic acid } \\
(\mathrm{nmol} / \mathrm{ml})\end{array}$ & $\mathrm{X} 0(\mathrm{n}=5)$ & $\mathrm{X} 1(\mathrm{n}=7)$ & $\mathrm{X} 2(\mathrm{n}=6)$ & $\mathrm{X} 3(\mathrm{n}=6)$ & $\mathrm{X} 4(\mathrm{n}=7)$ & $\mathrm{p}^{1}$ \\
\cline { 2 - 6 } & $3.46 \pm 0.737$ & $3.56 \pm 0.743$ & $3.44 \pm 1.017$ & $3.52 \pm 0.814$ & $3.52 \pm 0.758$ & 0.997 \\
Before & $3.77 \pm 0.706^{\mathrm{a}}$ & $2.83 \pm 1.052^{\mathrm{b}}$ & $3.65 \pm 0.581^{\mathrm{a}}$ & $3.49 \pm 0.52^{\mathrm{a}}$ & $2.66 \pm 0.458^{\mathrm{b}}$ & 0.030 \\
After & $0.32 \pm 0.935$ & $-0.72 \pm 0.761$ & $0.21 \pm 0.563$ & $-0.03 \pm 1.012$ & $-0.93 \pm 0.994$ & 0.058 \\
$\Delta$ pre-post & $9.18 \pm 2.7$ & $-20.18 \pm 2.14$ & $6.09 \pm 1.64$ & $-0.98 \pm 2.87$ & $-25.94 \pm 2.77$ & \\
\% Decrease & 0.489 & 0.047 & 0.404 & 0.937 & 0.048 & \\
p $^{*}$ & & & &
\end{tabular}

*Paired t-test, ${ }^{1}$ One-way ANOVA, ${ }^{\mathrm{a}, \mathrm{b}}$ On the similar line, the number with same letters show no significant differences between the grup ( $p>0.05$ ) (Post Hoc LSD)

levels of rats on the $\mathrm{X} 1$ and $\mathrm{X} 4$, that given multivitamin and $6 \mathrm{ml}$ dose of red pomegranate juice. While X3 that given $4 \mathrm{ml}$ dose of red pomegranate have an insignificant decline. The difference in mean changes of blood lactic acid levels before and after interventions between all 5 groups were analysed using One-way ANOVA test. The result was no meaningful difference between average levels of distinction lactic acid in blood of rats between groups, but there was a meaningful difference between average blood lactic acid levels of rats after the intervention $(\mathrm{p}<0.05)$. Advanced LSD Post Hoc test results showed that there was a meaningful difference in terms of average levels of blood lactic acid in group X0 with $\mathrm{X} 1$ and group $\mathrm{X} 4$ with $\mathrm{X} 0, \mathrm{X} 2$, and $\mathrm{X} 3(\mathrm{p}<0.05)$. The blood lactic acid levels of X4 has the largest declined $(-25,74 \pm 2.77 \%)$ than $\mathrm{X} 1(-20,18 \pm 2.14 \%)$. Group X0 and X2 have elevated blood lactic acid levels each $(9.18 \pm 2.7 \%)$ and $(6.06 \pm 1.64 \%)$.

The results of this study are in line with previous research about the intervention of Temulawak Extract Contains Curcumin (TECC) for 17 days to athlete at the Students Education and Training Center in Salatiga, Central Java. The subject were given physical activity of $5,000 \mathrm{~m}$ run and showed a decrease in the levels of lactic acid in the intervention group with $750 \mathrm{mg}$ TECC. The lactic acid was lower compared with placebo, $250 \mathrm{mg}$ TECC, and $500 \mathrm{mg}$ TECC groups ( $<<0.05)$ (Rosidi et al. 2013). Lactic acid buildup occurs because the formation of lactic acid is faster than its decomposition. The build up of lactic acid can be used as indicators of fatigue. The level of fatigue effect on endurance athletes during practice and games (Bahri et al. 2009). The control group (X0) and X2 (2 ml pomegranate juice) is the group that experienced a build up of lactic acid, reflected of unavailability or inadequacy of external antioxidant.

Lactic acid levels in normal condition (regular activities) with aerobic metabolism is under $4 \mathrm{mmol} / \mathrm{l}$ and above it classified as anaerobic threshold. Before the intervention, average lactic acid levels were found $3.52 \pm 0.76 \mathrm{mmol} / 1$, under the anaerobic threshold. At resting period, normal range of blood lactic acid is $0.5-2.2 \mathrm{mmol} /$ land in fatigue is in the range $20-25 \mathrm{mmol} / 1$, although also found more than $30 \mathrm{mmol} / 1$ of lactic acid level. Study by Rosidi et al. (2013) showed average levels of blood lactic acid before intervention with curcumin extract in athlete is higher than the regular activity of blood lactic acid levels at rest. This condition indicate the subject experienced fatigue, that blood lactic acid levels in resting period is above the average levels of blood lactic acid in regular activites. Based on Nalbandian et al. (2017), doing excessive physical activity continuously will cause a damage in the respiration chain due to oxidative stress. This condition characterized by high levels of MDA and will result in the inability of oxidative phosphorylation to produced ATP. Then, glycolytic lactic became the only source of energy. The formation of ATP via glycolytic lactic will have an impact on the build up of lactic acid. The provision of the red pomegranate juice that high in antioxidants as the intervention aimed at preventing damage to the mitochondrial membranes and the respiratory chain caused by free radicals.

\section{CONCLUSION}

The provision of red pomegranate juice significantly decreased the levels of MDA and blood lactic acid in rats with maximum physical activity with the dosage of $6 \mathrm{ml}$. The research suggests that athletes who do excessive physical activity should consume pomegranate cider as much as $360 \mathrm{ml}$ because it contains antioxidants to minimize the occurrence of oxidative stress and the buildup of lactic acid.

\section{ACKNOWLEDGEMENT}

Credits given to the to the laboratory staffs of UNDIP who had helped the process of research. The authors have no conflict of interest. 


\section{REFERENCES}

Bahri S, Joseph I, Sigit JI, Yusanti DP. 2009. Kadar asam laktat hasil metabolisme anaerob pada atlet. Jurnal IPTEK Olahraga 11(1):59-84.

Dasgupta A and Klein K. 2014. Antioxidants in food, vitamins and supplements Chapter 2: Methods for measuring oxidative stress in the laboratory. Elsevier. 2014:1920. https://doi.org/10.1016/B978-0-12405872-9.00002-1.

Guyton A, Hall J. 2011. Textbook of medical physiology $12^{\text {th }}$ ed. Singapore: Elsevier.

Harun I, Susanto H, Rosidi A. 2017. Pemberian tempe menurunkan kadar malondialdehyde (MDA) dan meningkatkan aktivitas enzim superoxide dismutase (SOD) pada tikus dengan aktivitas fisik maksimal. J Gizi Pangan 12(3):211-216.

Jawi M, Suprapta DN, Subawa AAN. 2008. Ubi jalar ungu menurunkan kadar MDA dalam darah dan hati mencit setelah aktivitas fisik maksimal. Jurnal Veteriner 9(2):65-72.

Jose MAS, Francesca G, Sara T, Tiziana C, Giuseppina DS, Ana MGP, Buelga SC, Busco F, Quiles JL, Cordero MD et al. 2014. One-month strawberry-rich anthocyanin supplementation ameliorates cardiovascular risk, oxidative stress markers and platelet activation in humans. J Nutr Biochem 25(3):289-294. http://dx.doi.org/10.1016/j. jnutbio.2013.11.002.

Lilach SD, Batya K, Shifra S, Ronit G, Liora O. 2014. Does pomegranate intake attenuate cardiovascular risk factors in hemodialysis patients?. Nutr J. 13(1):1-8 http://dx.doi. org/10.1186/1475-2891-13-18.

Mphahlele RR, Fawele OA, Mokwena LM, Opera UL. 2016. Effect of extraction method on chemical, volatile composition and antioxidant properties of pomegranate juice. S Afr J Bot 103(1):135-144.http:/dx.doi. org/10.1016/j.sajb.2015.09.015

Nalbandian HM, Radak Z, Takeda M. 2017. Active recovery between interval bouts reduces blood lactate while improving subsequent exercise performance in trained men. MDPI 5(2):1-8. http://dx.doi. org/10.3390/sports5020040

Purnomo M. 2011. Asam laktat dan aktivitas sod eritrosit pada fase pemulihan setelah latihan submaksimal. MIKI 1(2):155-170.
Quinn MJ, Cooper N, Rachet B, Mitry E, Coleman MP. 2008. Survival from cancer of the breast in women in England and Wales up to 2001. Br J Cancer 99(1):S53-S55. http:// dx.doi.org/10.1038/sj.bjc.6604587.

Rosidi A, Khomsan A, Setiawan B, Riyadi H, Briawan D. 2013. Efikasi pemberian ekstrak temulawak (Curcuma xanthorrhiza Roxb) dan multivitamin mineral terhadap penurunan kadar asam laktat darah atlet. MGMI 5(1):60-70.

Saputro DA, Junaidi S. 2015. Pemberian vitamin c pada latihan fisik maksimal dan perubahan kadar hemoglobin dan jumlah eritrosit. JSSF 4(3):32-40.

Sayuti K, Yenrina R. 2015. Antioksidan alami dan sintetik. Padang: Andalas University Press.

Sreekumar S, Sithul H, Muraleedharan P, Azeez JM, Sreeharshan S. 2014. Pomegranate fruit as a rich source of biologically active compounds. Biomed Res Int 2014(686921):111. http://dx.doi.org/10.1155/2014/686921

Susanna K. 2011. Oxsidative stress in skeletal muscle after acute exercise. [Dissertation]. University of East Finland

Syamsudin MB. 2013. Nutrasetikal. Jakarta: Graha Ilmu.

Trexler ET, Smith-Ryan AE, Melvin MN, Roelofs EJ, Wingfield HL. 2014. Effects of pomegranate extract on blood flow and running time to exhaustion. Appl Physiol Nutr Metab 39(9):1038-1042. http://dx. doi.org/10.1139/apnm-2014-0137

Turner JE, Hodges NJ, Bosch JA, Aldred S. 2011. Prolonged depletion of antioxidant capacity after ultra endurance exercise. Med Sci Sports Exerc 43(9):1770-1776. doi: 10.1249/MSS.ObO.

Vegara S, Mena P, Marti N, Saura D, Valera M. 2013. Approaches to understanding the contribution of anthocyanins to the antioxidant capacity of pasteurized pomegranate juice. J Food Chem 141(3):16301636. http://dx.doi.org/10.1016/j.foodchem.2013.05.015

Wang L, Muxin G, Mishida H, Shirakawa C, Sato S, Konishi T. 2007. Psychological stress-induced oxidative stress as a model of sub-healthy condition and the effect of TCM. eCAM 4(2):192-202. http://dx.doi. org/10.1093/ecam/nel080 